Covered in: Web of Sciences (WOS); EBSCO; ERIH+; Google Scholar; Index Copernicus; Ideas RePeC; Econpapers; Socionet; CEEOL; Ulrich ProQuest; Cabell, Journalseek; Scipio; Philpapers; SHERPA/RoMEO repositories; KVK; WorldCat; CrossRef; CrossCheck

2018, Volume 10, Issue 4, pages: 249-264 | doi: https://doi.org/10.18662/rrem/86

\section{Methodological Guidelines for Elaborating the Curriculum of Intercultural Education with a Focus on the Values of Tolerance}

\section{Ioana BOGHIAN1}

${ }^{1}$ Lecturer PhD, "Vasile Alecsandri" University of Bacău, Bacău, Romania, rahela_bac@yahoo.co.uk, boghian.ioana@ub.ro

\begin{abstract}
Our paper proposes a series of methodological guidelines for elaborating the curriculum of intercultural education with a focus on the values of tolerance. The aim is to provide curriculum suggestions for intercultural education as a discipline in adult education undergraduate and graduate study programmes. The present work relies on a thorough literature review on values promoted by intercultural education, the opportunities provided by intercultural education to promote non-discrimination values and attitudes in the context of an increasingly globalised world and labour market, defined primarily by versatility and intercultural / multicultural work settings and teams. Our experimental research aim is to provide evidence that IE can be a decisive factor in building tolerance-related attitudes and methodological guidelines on how IE may be implemented in adult education.
\end{abstract}

Keywords: intercultural education; curriculum; methodological guidelines; values; tolerance.

How to cite: Boghian, I. (2018). Methodological Guidelines for Elaborating the Curriculum of Intercultural Education with a Focus on the Values of Tolerance. Revista Romaneasca pentru Educatie Multidimensionala, 10(4), 249-264.

https://doi.org/10.18662/rrem/86 
Methodological Guidelines for Elaborating the Curriculum of Intercultural ...

\section{Introduction}

Etymologically, the word "value" (Latin, valere) means to be strong, to be worth/to deserve something. Depending on the field, the concept of value acquires different meanings: the object of moral preferences/choices or the criterion of moral conduct (ethics); value as a price that supports trade vs. value that cannot be commercialized, absolute, intrinsic (moral philosophy); the social norm that regulates social cohabitation (sociology) (Drago \& Boroli, 2004: 1152); an ideal associated with well-being and respectability; a key feature of values is their relativism, that is, they can vary according to age, historical moment, generation, culture, etc. (Ferreol \& Jucquois, 2005: $660)$.

The values of education are values related to the finality, content, methodology and epistemology of education (Pâslaru, 2003: 104). For a brief presentation of the classification criteria and types of values, see Boghian (2017b). Given that young people are constantly faced with the need to choose responsibly, the origin and content of values, selection criteria and internalization strategies in individual consciousness and behaviour must be clarified as very relevant aspects for building educational strategies focused on training and promoting values (Pichiu \& Albuț, 1994: 68).

Considering the relevance of the teacher's role of model for students of all ages, Cojocariu and Albu have conducted a longitudinal study on the values of Romanian teachers at different educational levels: values held by students (with or without teaching experience) preparing for the teaching career in primary and preschool education - truth, good, equity, patience, responsibility, love for others (Cojocariu, 2014); the axiological universe of primary school teachers - truth, equity, faith in God, professionalism and of preschool teachers - respect, work, honesty, professionalism (Cojocariu, 2015a); the values of senior and young university professors - morality, love for people and faith in God, and values that teachers consider to be the most important for university teaching - professional competence, student appreciation, dignity (Albu \& Cojocariu, 2015a); values appreciated by secondary school teachers - respect, work and self-education/self-development, professionalism (Cojocariu, 2015b); comparing the values held by students (with or without teaching experience) that prepare for the teaching career in primary and preschool education at the beginning of two successive academic years (Cojocariu, 2015c).

In recent years, there has been increased promotion of values associated with the practice of tolerance: harmonious cohabitation, respect for the rights of others, acceptance of diversity, free choice of value options (Boghian, 2017a). 
In our literature review we have identified the teachers' perspective on tolerance education; the conclusions were:

- education for tolerance is associated with intercultural education (IE) in a relevant number of papers and articles;

- increased tolerance capacity is a means and purpose of IE;

- examples of (in)tolerance should be used as a teaching material to raise awareness of the different dimensions and meanings of tolerance;

- tolerance is a central value of $21^{\text {st }}$ century education;

- tolerant attitude and tolerant behaviour are acquired based on patterns, starting with the earliest age;

- school is a small society, suitable for raising awareness of the phenomenon of tolerance and practicing it in several circumstances and relationships;

- tolerance is not a feeling inherited by birth, but acquired through education;

- the implementation and development of tolerance education is hampered by the fact that teachers, parents, students, other actors involved in the educational process do not understand the goals, principles and usefulness of learning tolerance (Boghian, 2016).

Considering the skills and attitudes essential to negotiating identity in society, Neuner (2012) highlighted the objectives of IE, namely:

- building empathy (attitude inclined towards trying to understand others in their own socio-cultural contexts), involving cognitive and affective aspects;

- the ability to build distancing (the ability to realize that not all people share our vision of our own world, the absence of which leads to stereotypes and prejudices), decentralization (the ability to go beyond its own frame of reference) and multiperspectivity;

- the tolerance of ambiguity (the ability to accept the fact that others are different from us and sometimes there are no definite answers about alterity and difference);

- self-awareness and identity representation (awareness of the sociocultural bases of one's world that influences one's vision of the world traditions, values, judgments - everyday life - routines, rituals, lifestyle formal attitudes and mentality, as well of how the individual relates this selfconsciousness to others;

- emotional openness for dealing with others in a multicultural environment; 
- giving up one's central position (creating a balance between dominant and shy people in a multicultural group to avoid exclusion and selfisolation);

- linguistic competence (mother tongue contributes to identity modelling, therefore understanding a language means better understanding of the speaker of that language) (Neuner, 2012: 35-38).

The following values have been identified as values associated with / promoted by IE in national and international works: tolerance, freedom, equality, respect for differences and the rights of others, solidarity, cooperation, empathy, acceptance of diversity (Albu \& Cojocariu, 2015b; Boghian, 2018; Chiriac \& Guțu, 2007; Cucoş, 2000; Haydon, 2007; Salgur,

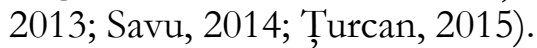

The theories of values elaborated by Romanian thinkers (Andrei, 1945; Blaga, 1996; Cojocariu \& Albu, 2015a, 2015b; Neculau, 2011; Vianu, 1998) are in line with the theories elaborated by foreign authors (Wlodkowski \& Ginsberg 1995; Reardon, 1997; Powell \& Caseau, 2004; Haydon, 2007; Polat, Arslan, \& Günçavdi, 2016), all of which converge to highlighting the value of good. This value is understood as consisting of three major meanings:

- an individual state of welfare;

- the well-being of a community;

- the act of doing good to others.

P. Andrei considers value not as a characteristic of the subject or object, but as a functional relationship in which these two factors cooperate (Andrei, 1945). The values we have identified as promoted by IE are associated with well-being understood as a state of well-being of a community: tolerance and acceptance of diversity, respect for others and the rights of others, empathy and compassion, love for others, solidarity and mutual help, and positive interpersonal relationships. Such values express a functional relationship - as Andrei argues - in which the subject (the individual) and the object (the community, the society, the world) cooperate for the welfare of all the actors involved; thus, the active dimension of values is emphasized: values do not simply exist as abstract entities but actually manifest themselves in behaviours that have a tangible cause (the desire to be tolerant, respectful, open, empathic, to show compassion, to give help) and the effect of these behaviours (better, positive interpersonal relationships, and, as a result, a better world).

Intercultural education courses and seminars help define and identify values in general, values associated with tolerance and peace education, and raise awareness of the importance and necessity of teaching and promoting these values in today's world. 


\section{Methodological guidelines for elaborating the curriculum of intercultural education with a focus on the values of tolerance}

\subsection{Intercultural education policies}

Intercultural education (IE) is a pedagogical approach to cultural diversity that considers the spiritual (cultural) and other peculiarities (gender, social or economic particularities) and tries to avoid the risks arising from all sorts of inequalities and differences. Intercultural interaction skills can be acquired by learning specific behaviours within formal, informal or non-formal educational influences.

In literature, there are several terms presented as equivalent or synonymous with IE: peace education, tolerance education, nondiscrimination education, civic education, all these terms orbiting around the learning of individual human rights and freedoms and the need to respect and protect them.

In the current world of globalization and cultural diversity, cultural competence is necessary for social and economic success; cultural competence means "appreciating the creative expression of ideas and emotions by all types of individuals", including aspects of personal, interpersonal and intercultural competence "highlighted through effective communication and collaboration" (Mishra \& Kereluik, 2011: 11). The literature interconnects cultural competence with the following key concepts: intercultural knowledge, civic knowledge and involvement, knowledge of culture and of the physical world, abilities for a global world (Zhao, 2009), communication in foreign languages, social civic competence, consciousness and expression of cultural identity (Council of Europe, 2011), global awareness (Partnership for $21^{\text {st }}$ Century Skills, 2007).

Our approach to elaborating the curriculum of IE with a focus on the values of tolerance considers the national and international laws and official documents related to this domain. One of the reference documents on our subject is the 1994 UNESCO guide on tolerance, which sets out guidelines for education based on and aimed at promoting democracy, peace and buman rights. The document Tolerance: the threshold of peace. A teaching/learning guide for peace, buman rights and democracy focuses on promoting tolerance education and describes approaches in primary and secondary education, being in fact a "study manual for all who can help educate for tolerance", inside and outside the school (UNESCO, 1994: 4).

In Europe, countries accept the recommendation of the Council of Europe on the question of teaching intercultural values; education centred on intercultural values, which are part of the so-called democratic values, 
namely those based on human rights, encourage attitudes, skills and concepts related to freedom, equality, democracy and individual responsibilities (Fernández, DeLuna, \& Eisman, 2014: 442). But each country differs in the way it implements the recommendations of the Council of Europe: for example, in Spain, intercultural values are taught in compulsory secondary education within the discipline of Citizenship Education and Human Rights, as well as through trans-curricular content aimed at acquiring by students the values of tolerance, civic cooperation and solidarity, awareness of the obligations towards others and the rights of others; gender equality; awareness and respect for cultural diversity, the history of one's own people and of other peoples (Eurydice, 2005).

In 1985, the Swedish Parliament assessed the need for an intercultural perspective in education as an approach - not a discipline - that should be included in all disciplines and that should comprise: intercultural teaching and learning, communication, school development and intercultural pedagogical research; the values on which interculturality is centred are explicitly mentioned in the Swedish National Curriculum: tolerance, mutual understanding, equality and solidarity, social justice, freedom and integrity of the individual; the best ways to encourage these values are: teaching critical thinking, linking classroom activities to discussions about students' everyday life, building intellectual cooperation and mutual respect in class, constructively exploiting differences between students, and building an attitude of openness and acceptance of differences in students (Tuomaala, 2013: 13).

In Norway, although there is no discipline focused only on intercultural issues, students learn about similar values - equality, equal chances, spiritual freedom, tolerance, ecological awareness and international collective responsibility - at disciplines such as: Social Studies, Christianity, Religion and ethics; Students Council (Fernández et al., 2014: 442).

In Romania, Order no. 1529 of 2007 of the Ministry of Education, Research and Youth addressed for the first time the issue of cultural diversity in the Romanian educational system and established the introduction of the specific elements of this problem in the curricula; a year later, the introduction of intercultural education as an optional discipline curriculum at school decision - for middle-school level education (Ivasiuc, Koreck, \& Kővári, 2010) was established. 


\subsection{Methodological guidelines for elaborating the curriculum of Intercultural Education with a Focus on the Values of Tolerance}

\subsubsection{The principles of intercultural education}

Intercultural education focused on the values of tolerance (IEVT) aims at enhancing tolerance values and forming a tolerant attitude that translates into acceptance of cultural, ethnographic, nutritional, gender, etc. diversity, the idea that there are no solutions to all problems and no single perspective on a situation characterized by conflict or risk of conflict based on discrimination.

Active tolerant attitude has been defined as the presence and manifestation of one or several of the following behavioural traits: patience, discretion, sensitivity, empathy, hospitality, compassion, respect, kindness, altruism (T,urcan, 2015).

The curriculum addresses teachers, students, and textbook authors, and capitalizes on the above-mentioned values of intercultural education and its principles described below.

The IEVT curriculum takes into consideration the principles of IE. A first principle of IE considers heterogeneity a norm (as a term from which the concept of "normality" was derived), and not a handicap requiring additional support. This heterogeneity, as a rejection of ethnic, cultural, identity and interest homogeneity, is the denial of totalitarianism and a means of guaranteeing the values of an open and democratic society. At the same time, intercultural education is not a way of levelling or compensating for inequalities, but a means of enhancing equality. Another principle of IE is the idea that individuals and, implicitly, the groups they are part of, are constantly subject to a process of cross-breeding, a producer of continuous diversity. Noteworthy here is the convergence of this principle with the constructivist perceptions of the concept of culture, according to which any culture is constantly changing due to its permeability to influences from the outside. When the idea of permanent dynamics of any culture is assumed, essentialist prejudices and rigid stereotypes are more vulnerable and easier to dismantle. Intercultural education also promotes a certain kind of cognitive dynamics of the student. It is about learning a movement from the centre of your own culture and its rules towards the outside, so that you can look at the values of alterity as much as possible from the other's point of view. This principle seems difficult to put into practice, since every individual is the product of one's own culture. From this point of view, there is no possibility of a tabula rasa state, whereby the individual can completely "get 
rid of" values internalized through education. What intercultural education brings in this process of relativizing one's personal values is the learning of openness towards otherness and the ability to understand it from the point of view of the other's values. This relativization of one's values must be achieved in an environment of continuous and reciprocal interaction. Judgments of value are removed, the difference is no longer stigmatized, but on the contrary, emphasis is placed on what the individuals have in common, which allows them to use the same language, understanding and mutual valorization. Thus, intercultural education is not only addressed to minority but also to members of the majority who have the same duty to relativize their own values, to combat stigmatizing value judgments and to value others.

Intercultural education promotes a constant dialogue, based on equality. Regarding terminological debates, it is possible to conceptualize a series of dichotomies between related concepts such as intercultural education/education for diversity, intercultural education / inclusive education, intercultural education/anti-bias education, etc.

\subsubsection{The values of intercultural education}

Works on values associated with/promoted by IE by Romanian authors have revealed the following aspects:

- education for all promotes respect for all, and everyone is regarded as a value (Bunăiaşu, 2015: 42);

- diversity and differences are viewed and addressed with respect and gratitude because "the greater the diversity, the richer our ability to create new visions of life" (Vrasmaș, Nicolae, \& Vrasmaș, 2008: 40);

- the particularities of society influence the way people define their own system of values; IE, defined primarily as "value education", is decisive in this respect; the values that IE promotes, and builds are: tolerance, acceptance, collaboration (Voinea, 2012: 290).

One of our questionnaire-based investigations aimed at identifying the values associated with/promoted by IE from the perspective of a group of 68 students from "Vasile Alecsandri" University of Bacău who are preparing for a primary and pre-primary teacher's career and who attended an optional intercultural education course in the first semester of the academic year 2017-2018 (2h course and 2h seminar per week) (Boghian, 2018). The analysis of the investigation data and the comparison between the data obtained in the questionnaire and the study of the literature (Boghian, 2017b) highlights the relevance and urgency of introducing 
intercultural education activities/lessons/modules/courses at the level of primary, secondary and university education; our findings are:

- both the literature review and the results of the questionnaire highlight the need for education for tolerance in today's globalized society;

- both the analysis of the literature and the results of the questionnaire reveal Intercultural Education as a discipline suitable for building, developing and promoting the values of tolerance and acceptance of diversity, respect for others and the rights of others, empathy and compassion, love for others and positive interpersonal relationships, solidarity, equality;

- both the literature review and the results of the questionnaire provide strong arguments for carrying out an experimental research that could show to what extent IE courses/modules/lessons/activities can affect tolerance levels and tolerance attitudes at different ages;

- although there is a theoretical agreement on teaching intercultural values at the international level, countries apply different practical approaches: in some countries, intercultural education is a separate, compulsory discipline, while in others there is no specific discipline but only topics of intercultural education in certain disciplines (languages, civic education, religion, etc.); based on an international collaboration program / project, a common framework of good practices may be developed to apply the intercultural approach of education in (at least) a number of countries, so that each nation may contribute to its development and benefit from the final result.

Building a state of mind that creates a greater tolerance capacity, openness to different values and behaviours does not necessarily mean accepting and assuming different values as one's own but the ability to understand them from the perspective of another culture/context; understanding and accepting cultural relativism means recognizing the equality of cultures and the fact that the values and norms of a culture cannot be used to judge other cultures.

\subsubsection{The aims and objectives of the IEVT curriculum}

The overall objective of the IEVT module is to build and develop tolerant attitudes and to increase tolerance attitudes where these already exist in the sense of recognizing and respecting human dignity by developing the capacity to accept diversity and to be actively involved in social life. The attitude of active tolerance is broadly understood as the ability to accept diversity and to be actively involved in social life. 
The aim of the IEVT module is to increase active tolerance attitudes by forming tolerant consciousness and emotional skills that reflect the social cultural and education level of the person.

The specific objectives of the IEVT module aim at forming certain attitudes, capacities and knowledge; after completing the IEVT module, the learners will be able to:

- explain the significance of tolerance and to know its components;

- explain and argue for the need for tolerant communication and manifestation of an active tolerant attitude;

- explain phenomena of social intolerance, to identify their causes and possible measures to eliminate / control / reduce these phenomena;

- identify and distinguish between moral values and nonvalues to accept in communication the diversity of axiological views;

- communicate empathically and express an open attitude during exchanges of opinions and ideas;

- demonstrate a pacifist approach in situations of intrapersonal and social conflict so that they can work together to find the most appropriate solution for solving them;

- develop and promote in every communication context principles and rules of communication in the spirit of the culture of tolerance;

- manifest emotional skills (constructive and creative spontaneity, assertiveness, emotional stability, empathy, sociability, self-knowledge);

- identify changes in their level of understanding of socio-cultural diversity and, implicitly, their level of tolerance towards active vulnerable persons / at risk of being discriminated against.

IEVT-specific activities target the use of content associated with the specific objectives listed above. The contents of the IEVT module are selected to meet specific objectives. The theme of intercultural education activities focusing on tolerance values may refer to the following contents and not only:

- The culture of respect; tolerance culture and tolerance values; tolerant attitude vs. intolerant attitude - characteristics;

- Discrimination legislation;

- Identity and stereotypes; affirmation of identity and celebration of diversity;

- The effects of stereotypes; prejudices and discrimination; equity and inequity;

- Approaches to diversity in education; adapting intercultural and anti-discrimination education to the Romanian context; 
- Development of strategies for preventing and combating prejudices and racism in class.

The contents listed above correspond to the specific objectives needed to increase the level of active tolerance attitudes, operationalized for adult learners, and which represent information about tolerance values and general-human values: good, truth, beauty.

The resources and didactic means necessary for the development of EIVT activities will support the application of the listed teaching methods: video projector, audio-video recordings, worksheets/opinion sheets, questionnaires, etc.

The activities of the IEVT module exploit classical and modern teaching-learning-evaluation and self-evaluation methods: exposition, conversation, demonstration, debate and problem-solving, explanation, exercises and reflection topics, case study, reciprocal learning/teaching method, the pyramid, the cube, the method of the 6 thinking hats, the jigsaw, the conceptual map, the tour of the gallery, the portfolio, etc.

The IEVT curriculum development directions refer to the competences, values and attitudes listed below.

\section{General competences}

1. Using the concepts specific to social sciences for organizing the approaches to knowledge and explanation of facts, events, real life processes.

2. Applying knowledge specific to social sciences in solving some problematic situations, as well as in analysing personal development possibilities.

3. Cooperating with others in solving theoretical and practical problems within the different groups.

4. Manifesting an active and responsible social behaviour, appropriate to a changing world.

5. Participating in decision-making and community problem solving.

$V$ alues and attitudes

- positive valorisation of cultural differences;

- positive attitude towards people and groups belonging to different cultures that hold different values, opinions and beliefs;

- respect for one's own cultural identity and the cultural identity of others;

- respect for dignity and human rights;

- tolerance and understanding;

- peaceful resolution of conflicts; 
- cultural empathy;

- civic spirit;

- availability for intercultural dialogue and cooperation.

The IEVT-curriculum suggestions on teaching content includes topics such as:

- The culture of respect and active tolerance;

- Discrimination legislation;

- Identity and stereotypes;

- The effects of stereotypes; prejudices and discrimination;

- Equity and inequality;

- Approaches to diversity in education;

- Adaptation of intercultural and anti-discrimination education to the Romanian context;

- Identity assertion;

- Celebrating diversity;

- Development of strategies for preventing and combating prejudices and racism in class;

- Reflection and (self-)evaluation.

The perspective from which intercultural education is addressed at each course and seminar is that of moral rules and values. Tolerance as a value and tolerant attitude is reflected in communication; increasing active tolerance attitudes can be achieved through the acquisition of tolerance values and their activation through the manifestation of behaviour based on active tolerance.

\section{Conclusions}

Our research at the level of the scientific literature and the regulatory documents of the Romanian education system allows us to formulate the following conclusions:

- the discipline of intercultural education does not have a compulsory status in any country, although foreign and Romanian authors emphasize the necessity of introducing it as a compulsory discipline for reducing/eliminating all types of discrimination and discrimination-based conflicts;

- both foreign and Romanian authors underline the potential of intercultural education to promote tolerance, with the aim of reducing/eliminating conflicts and situations of discrimination;

- the values associated with tolerance most often are respect and mutual help/support/solidarity, according to the literature studied; 
- we could not identify a scale to measure attitudes and meet the needs of our research goals; it will have to be compounded by combining and adapting items in existing scales of tolerant/non-discriminatory attitudes;

- the literature presents the social determinations of education for tolerance in the contemporary world, both at the level of the educational context and at the level of the sociocultural factors, emphasizing the importance of the scientific foundation of education for tolerance as a new challenge of education.

Our analysis of the national curriculum for pre-university education has enabled us to note the shortcomings of the learning outcomes and contents of tolerance education, hence there is a clear need to develop a module on this dimension of education in a multicultural society.

There are optional IE courses in academic education, but only in some Romanian universities; these are a starting point in developing an intercultural education module focused on tolerance as a key value, as well as a confirmation of the certainty of the need for intercultural education in a world that is becoming increasingly globalized, globalizing and diverse, which must, however, stand together and overcome conflicts in a constructive way in order to evolve.

Our research aims to design and teach a module of Intercultural Education centred on tolerance values for students from the $3^{\text {rd }}$ year of various specializations and faculties at "Vasile Alecsandri" University of Bacau with the aim of identifying and measuring the possible changes in their tolerant, anti-discriminatory attitudes. To this end, we intend to apply a pre-test and post-test (a Likert-type scale for identifying and measuring tolerant/anti-discriminatory attitudes) and compare the results obtained before and after the students' attendance and study of the module of Intercultural Education.

The analysis and interpretation of the data from the tests applied before and after the experimental phase may enable us to formulate conclusions on the efficiency of using intercultural education to change attitudes related to tolerance at adults.

The main hypothesis is that attending the intercultural education module will enhance the tolerant and non-discriminatory attitudes of the students: their desire for intercultural knowledge and their level of acceptance of the diversity and difference that define people of different ethnicities, nationalities, religions, etc. will increase Also, the intercultural education module will address students who attend the initial program of psycho-pedagogical training for the teaching career because they are 
potential future teachers who can promote an open and tolerant attitude among their students, first of all through the model of behaviour and attitude they will provide themselves.

Our intention is also to concretize the results of our research into a best-practices guide on achieving intercultural education that includes methodological and content suggestions focused on the development of a tolerant, anti-discriminatory attitude.

\section{Acknowledgment}

The article has been presented at The XIX ${ }^{\text {th }}$ Congress of the AMSE-AMCEWEAR, 4 - 7 June 2018, Stefan cel Mare University of Suceava, Romania.

\section{References}

Albu, G., \& Cojocariu, V.-M. (2015a). Intercultural education - Tensions and prospects case study - The approach of the 1 st -year students from the pedagogy of primary and pre-school education. Procedia - Social and Behavioral Sciences, 209, 53-60.

Albu, G., \& Cojocariu, V.-M. (2015b). Axiological tensions and options in the Romanian academic environment: Intergenerational comparative study. Procedia - Social and Behavioral Sciences, 171, 24-33.

Andrei, P. (1945). Filosofia valorii [Philosophy of value]. Bucharest, Romania: Fundația Regele Mihai I.

Blaga, L. (1996). Trilogia valorilor III. Artă şi valoare. Bucureşti, Romania: Humanitas.

Boghian, I. (2016). Teachers' perspectives on tolerance education. A literature review. Journal of Innovation in Psychology, Education and Didactics, 20(2), 136142.

Boghian, I. (2017a). A psycho-pedagogical approach to the concept of tolerance. Journal of Innovation in Psychology, Education and Didactics, 21(1), 97-110.

Boghian, I. (2017b). The values of tolerance education. A literature review. Journal of Innovation in Psychology, Education and Didactics, 21(2), 205-220.

Boghian, I. (2018). Values promoted by intercultural education. In Proceedings of CIEA 2018 - The Fifth International Conference on Adult Education. Education for values - continuity and context (pp. 383-390). Bologna, Italy: Editografica.

Bunăiaşu, C. M. (2015). Developing programs of intercultural education, with regard to the inclusive education's value. International Letters of Social and Humanistic Sciences, 57, 42-47.

Chiriac, A., \& Guțu, V. (2007). Curriculumul intercultural: orientări, principii, resurse. Pedagogie, 9, 75-77. 
Cojocariu, V.-M. (2014). Is there an axiological background favouring the initial training in the didactic career for the primary and preschool didactic career?. Procedia - Social and Behavioral Sciences, 137, 100-104.

Cojocariu, V.-M. (2015a). Anchor-values of the axiological universe of primary teachers. Procedia - Social and Behavioral Sciences, 180, 524-530.

Cojocariu, V.-M. (2015b). Is there a set of nucleus-values characteristic of teachers from middle education? Procedia - Social and Behavioral Sciences, 203, 84-89.

Cojocariu, V.-M. (2015c). The evolution of the axiological system of students training for a teaching career. Procedia - Social and Behavioral Sciences, 191, 2382-2386.

Council of Europe (2011). Common European framework of reference for languages: Learning, teaching, assessment. Retrieved from https://rm.coe.int/16802fc1bf

Cucoş, C. (2000). Educația. Dimensiuni culturale şi interculturale. Iaşi, Romania: Polirom

Drago, M., \& Boroli, A. (Eds.) (2004). Enciplopedie de filosofie și științe umane [Encyclopaedia of philosophy and human sciences]. Bucharest, Romania: All.

Eurydice. (2005). Citizenship education at school in Europe. Retrieved from http://www.indire.it/lucabas/lkmw_file/eurydice/Citizenship_scho ols_Europe_2005_EN.pdf

Fernández, M. T., DeLuna, E. B., \& Eisman, L. B. (2014). Intercultural values education in Europe. A comparative analysis of Norwegian and Spanish reality. Procedia - Social and Behavioral Sciences, 132, 441-446.

Ferreol, G., \& Jucquois, G. (Coords.). (2005). Dicționarul alterității şi al relațiilor interculturale. Iaşi, Romania: Polirom.

Haydon, G. (2007). Values in education. London, UK: Bloomsbury Publishing.

Ivasiuc, A., Korek, M., \& Kövári, R. (2010). Educația interculturală: de la teorie la practică. Implementarea educației interculturale în şscoli multietnice din România. Research Report of the Agency for Community Development "Impreună". Retrieved from

http://www.agentiaimpreuna.ro/uploads/educatia\%20interculturala. pdf

Mishra, P., \& Kereluik, K. (2011). What 21st Century Learning? A review and a synthesis. Michigan, USA: Michigan State University.

Neculau, B. C. (2011). Nevoia de educație interculturală astăzi, calea spre o societate tolerantă. In Toleranța-cheia ce deschide calea spre o lume nouă, a unității prin diversitate (pp. 34-36), international symposium. Iaşi, Romania: Spiru Haret University. 
Neuner, G. (2012). The dimensions of intercultural education. In J. Huber (Ed.), Intercultural competence for all. Preparation for living in a beterogeneous world (pp. 1150). Strasbourg, France: Council of Europe Publishing.

Partnership for 21st Century Skills (2007). Framework for 21st century learning. Retrieved from

http://www.p21.org/storage/documents/1._p21_framework_2pager.pdf

Pâslaru, V. (2003). Principiul pozitiviv al educației. Chişinău, republic of Moldova: Litera. Pichiu, D., \& Albuț, C. (1994). Teoria valorii şi elemente de praxiologie. Iaşi, Romania: Gh. Asachi.

Polat, S., Arslan, Y., \& Günçavdi, G. (2016). The qualities of teachers who instruct peace education: Views of prospective teachers' who attended the peace education programme. Journal of Education and Practice, 7(28), 36-45.

Powell, R. G., \& Caseau, D. (2004). Classroom communication and diversity. Mahwah New Jersey, London: LEA.

Reardon, B. (2004). Toleranţa - calea spre pace. Chişinău, Republic of Moldova: ARC.

Salgur, S. A. (2013). The importance of the teacher in intercultural education. International Journal of Global Education, 2(1), 1-5.

Savu, E. (2014). The 'intercultural' teacher - a new response to the teaching career. Procedia - Social and Behavioral Sciences, 128, 111-116.

Tuomaala, S. (2013). Behaviourism versus intercultural education in the novel purple hibiscus. Södertörn, Sweden: Södertörn University. Retrieved from http://sh.divaportal.org/smash/get/diva2:627369/FULLTEXT01.pdf

Țurcan, L. (2015). Formarea cadrelor didactice prin valorile toleranţei. Chişinău, Republic of Moldova: Tipografia UPSC "Ion Creangă".

UNESCO. (1994). Tolerance: The threshold of peace. A teaching/learning guide for peace, buman rights and democracy. Retrieved from http://www.unesco.org/education/pdf/34_57.pdf

Vianu, T. (1998). Introducere în teoria valorilor. Bucureşti, Romania: Nemira.

Voinea, M. (2012). The role of intercultural education in defining the system of individual values. Procedia - Social and Behavioral Sciences, 33, 288-292.

Vrasmaş, E., Nicolae, S., \& Vrasmaş, T. (2008). Paşi spre educația incluð̌ivă în România. București, Romania: UNICEF.

Wlodkowski, R. J., \& Ginsberg, M. B. (1995). Diversity and motivation: Culturally responsive teaching. San Francisco, USA: Jossey-Bass.

Zhao, Y. (2009). Catching up or leading the way. Alexandria, USA: ASCD. 